\title{
KDM2B Gene
}

National Cancer Institute

\section{Source}

National Cancer Institute. KDM2B Gene. NCI Thesaurus. Code C120057.

This gene is involved in demethylation of histone $\mathrm{H} 3$. 